\title{
Conversion-Option Debentures
}

\section{Leonard Chazen $\uparrow$ \\ Leonard Rosst†}

In the late 1960's, the Depression survived only in the speeches of William McChesney Martin, and the proportion of debt in the capital structure of many corporations was allowed to increase. Conglomerates grew by transmuting the blue-chip common of acquired companies into the conglomerate's own convertible debentures, thereby saving taxes and in some cases, eliminating large numbers of minority stockholders. American firms operating abroad found debt more acceptable to foreign investors than common stock. But with so many high debt equity ratios, it may take far less than a depression to jeopardize the solvency of many large corporations. Some firms are already experiencing a hangover from the leverage binge of a few years ago, and must now jettison subsidiaries to lighten the debt load. This spectre of bankruptcy is a concern not only to the executives and investors whose jobs and holdings are imperiled. Congressmen have recently warned against the dangers of employing fancy-featured securities 1 and the New York Stock Exchange has de-listed some debentures because of a high default risk. ${ }^{2}$ Such fears could to some extent be alleviated if it were possible to issue debt without increasing the possibility of bankruptcy. This article suggests one method of doing so.

Corporate reorganization or bankruptcy involves more than a reshuffling of corporate assets among different classes of security holder -the pie shrinks while being split. Bankruptcy proceedings and reorganizations are notoriously costly. Aside from their direct cost in legal fees, fights among different classes of creditors and stockholders may consume management energy, preclude new investments, and upset normal business relationships. ${ }^{3}$ Because investors are unsure of

$\dagger$ Member of the New York Bar. LL.B., Yale Law School, 1967.

H Ph.D. candidate in Economics, Yale University; LL.B. Yale Law School, 1967.

The authors wish to thank Profs. Boris Bittker, William Brainard, Victor Brudney and Marvin Chirelstein, and Mr. Steven Fenster for their helpful comments, and MIr. Charles Dunetz for research assistance.

1. Wall Street Journal, March 25, 1969, at 1, col. 6.

2. The delisted issues were \$16 million of Gencral Host Corporation 7\% subordinated debentures, due in 1974, and \$102 million of NVF Co. $5 \%$ subordinated debentures due in 1994. The stock exchange found that interest payments on the bonds might exceed available earnings, and that common equity in the corporation would amount to less than $25 \%$ of total capitalization.

3. See Baxter, Leverage, Risk of Ruin and the Cost of Capital, 22 J. FmuNar 395 (1967). 
the capital structure which will emerge from the reorganization, security prices tend to fall even farther than the business shipwreck warrants.

Even if default and reorganization do not occur, the anticipation by investors that such steps might be necessary entails an expense to the corporation. A corporation's choice of capital structure is, at present, largely dictated either by management's fear of insolvency or that of its creditors. Lenders know that security for their loans cannot fully protect them against bankruptcy costs, and they will usually include in their mortgage indenture a limitation on further borrowing. However, since interest on debt is deductible and dividends on equity are not, the ideal capital structure should stress debt. ${ }^{4}$ If ruin were no longer in prospect, management could maximize stockholder profits by hiking the debt-equity ratio as high as tax law would permit. Apart from this tax advantage, high debt-equity ratios may represent the most efficient means of allocating risk in the economy. Since corporations can borrow at lower transaction costs than individuals, efficiency re. quires that corporate stock rather than individual portfolios be highly levered. Risk-seeking individuals could achieve the effect of personal leverage by buying stock while more cautious investors could hold a larger proportion of bonds. ${ }^{5}$

For the above reasons, we believe that it would be worthwhile to alter the form of debt securities so as to reduce the risk and cost of reorganization. Several methods are conceivable, some of which have

4. A recent statement by the chief executive of Bethlehem Stecl indicates that corpo rate management perceives the advantages of leverage:

People overlook [the capital investment problems] when they say, "Well, take your coats off. Go out there in the world market and fight these people. You're inventive and ingenious and so forth, and you've always fended them off before." They overlook the difference in the capital structures of the rest of the world's steal industry and the American steel industry. In the United States, the capital structure is an average of 25 per cent debt and 75 per cent equity. And anywhere else in the world, you find the reverse- 75 or 80 per cent debt and 20 per cent equity. And people don't think that that creates a rather unequal area to compete in, but lct me tell you. The Japanese, in the steel industry, if they make $2 \frac{1}{2}$ per cent net profit on revenue dollars, they're having a fine year. At twice that, we're having a terrible year. We can't pay our equity holders a dividend. The Japanese, at $21 / 2$ per cent, can pay a 10 per cent cash dividend to the few stockholders they have and the banks couldn't care less, is long as the steel people cover the debt service. So that if I were over there in Japan, boy, anything over that debt service would look like a good price-as far as setting your price in your market is concerned.

N.Y. Times, Nov. 28,1969 , at 13, col. 1.

5. See Modigliani and Miller, The Cost of Capital, Corporation Finance and the Theory of lnvestment, 48 AM. EcoN. REv. 261 (1958); Baumol and Malkicl, The Firm's Optimal Debt-Equity Combination and the Cost of Capital, 81 Q. J. EcoN. 547 (1967). The latter conclude: "In general, the tax advantages of bond financing and the near zero transactions costs incurred in undoing leverage make it desirable for the firm to employ as much debt as is consistent with considerations of financial prudence." $1 d$. at 571 , 
already been tried. The indenture agreement might grant the company a grace period before the subordinate creditors could throw it into bankruptcy. This stop-gap measure, however, is of real help only to those debtors who are temporarily embarrassed. The mere availability of a stay of execution is unlikely to soothe management's apprehension about raising the debt ratio. In addition, a grace clause would often increase the costs of insolvency by extending a corporation's already prolonged last rites.

Majority clauses are a more traditional means of avoiding formal reorganization. The typical clause allows a majority (simple or larger) of any class bondholders to compromise the rights of the entire class to principal, interest or both. No fiduciary duty is imposed on the bondholders in voting for a compromise, although in cases of stark conflict of interest some duty may be inherent. But majority clauses were subject to abuse during the reorganizations of the 1930s, and are now severely limited by the Trust Indenture Act of $1934 .{ }^{\circ}$ A threequarters vote is required for any compromise. Principal cannot be affected and no more than two years' interest may be sacrificed. Thus major overhaul of the corporate capital structure by majority vote is no longer possible. However, even with flexible majority clauses, the delays and transaction costs inherent in creditor-voted reorganizations would be sufficient to discourage higher debt-equity ratios.

Another possibility is to adapt to debt securities the practice of giving preferred shareholders of a company the right to elect several members of the board of directors whenever the company is delinquent in paying dividends. But this procedure might make the bond indistinguishable from preferred for tax purposes. In addition, there are intractable conflict-of-interest problems involved in class representation on boards of directors.

Rather than give bondholders a partial right to govern the defaulting corporation, we propose to turn them into common stockholders before the default occurs. Companies would issue "conversion option" bonds, which would give the corporation the option at any time to convert the bonds into common stock at a specified penalty rate. ${ }^{8}$ This conver-

6. 15 U.S.C. $\S 77$ (1964).

7. Id.

8. To our knowledge, the only public issue of a similar security was by Associated Gas \&: Electric Utility Corporations, one of the fashionable public utilities holding companies of the 1920 's. In 1928, Associated issued $51 / 2 \%$ investment certifieates, convertible at the option of the holder into a bouquet of common and three types of preferred stock of an affiliate, Eastern Utilities Investing Corp. After 5 jears, the certificates would be convertible at the issuer's option into $\$ 5.50$ dividend series preferred stock of Associated Gas 
sion ratio would be several times more favorable to the bondholders than the ratio of bond to stock price prevailing at the time the bond was issued. For example, if the "conversion option" were attached to an ordinary convertible, which the investor could exchange for one share of common, management could force conversion but would be required to issue four shares of common in return. The ratio would be set sufficiently high so that management, representing the common shareholders, would make use of the option only when default was no longer a remote prospect.

To begin, let us assume that the object of the conversion-option feature is to approximate the rearrangement of corporate control that would follow from a Chapter $\mathrm{X}$ reorganization. The objective may be modified to include the allocation to stockholders and bondholders of the savings realized from avoiding the reorganization proceedings which would have resulted if the holders of conventional indebtedness had been free to enforce their rights. There are obvious problems in trying to set a conversion ratio which will in all circumstances leave the debt holders as well off as under a conventional reorganization. In such a bankruptcy proceeding, former holders of debt are supposed to receive new securities equal in value to the face amount of their old bonds or debentures. Their position in the post-reorganization capital structure, relative to the former shareholders, depends therefore on the face amount of the bonds, and the net worth of the corporation at the time of reorganization. When the indenture is drawn, only the former is known. Because the latter is highly unpredictable, it is difficult to determine the possible outcome of a Chapter $\mathrm{X}$ proceeding. But the conversion option has to fix the relative shares of stockholders and bondholders in advance. If bondholders are given more by the option than they would receive in a bankruptcy reorganization, management will probably choose a Chapter $\mathrm{X}$ proceeding anyway in order to avoid too great a damage to stockholder equity. If they are given less, we will fail in our objective of giving bondholders at least what they would reap from a Chapter $\mathrm{X}$ proceeding.

The surplus realized from avoiding reorganization costs can remedy these faults to some degree. Even if the holders of conversion option

\& Electric Co. at the rates of one share for each $\$ 100$ par value. These provisions are recounted in Associated Gas \& Electric Utility Corporations, SUMMary REFort Or Tite

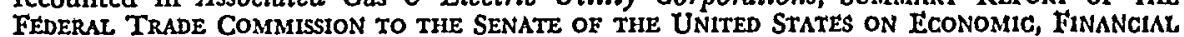
and Corporate Phases of holding and Operating Companies of Fuegtric and Gas Urumres 306-307 (1935). In conversation, we have heard that conversion option sccuritles have been used occasionally in private placements. 
debt receive a smaller share of the company than they would have obtained in a bankruptcy reorganization, the diminished share, sans reorganization costs, may be worth more than a larger piece of the company, had it endured a Chapter $X$ reorganization. The savings from avoiding bankruptcy are not limitless, however, and the holders of conversion option debt will face some contingencies in which they will be positively worse off as a result of the conversion option.

Alternatively, we may modify this objective. A "conversion option" bond can represent a new allocation of the risk and return available from the corporation, involving a somewhat greater sharing of downside risk than is customary in debt securities. Such relatively high risk debt would not, of course, appeal to all investors who presently hold fixed-obligation securities. Corporate debt is held in large amounts by banks and other financial institutions, which must themselves meet fixed obligations, and which require maximum assurance of receiving a security's face amount at maturity. Furthermore, the ability of such institutions to participate in higher risk debentures is limited by federal and state regulation. Such institutions would not be customers for this type of conversion option debenture.

In recent years, however, the emergence of convertible debentures has brought a new kind of customer into the debt market-one who has more in common with equity investors than with risk-averse financial institutions. Such investors buy convertible debt instead of stock for several reasons, including the lower margin requirements applicable to convertibles and the availability of a downside hedge along with an upside speculation. No doubt, they place some value on the debt holder's traditional assurance that, in the event of insolvency, debt holders receive face value in reorganization securities before equity investors receive anything. Such safeguards are certainly not as important for investors in convertibles as they are for more senior lenders. ${ }^{9}$ If management is allowed to exercise the conversion option at a 3-1 or 4-1 penalty rate, a sufficient hedge against downside risk will probably exist to attract the ordinary investor in convertible debt. To the extent that he is assuming a greater risk, compensation may be offered in the form of a higher interest rate or a more attractive upside conversion price. Our earlier discussion suggests that corporate managements would have ample reason to offer this compensating premium. The company would be avoiding potential reorganization

9. The frequent gap between reorganization values and market valucs raised some questions about the sorth of this guarantee to any class of debt holder. 
expenses. Management's own jobs would be more secure from a perilous passage through Chapter X. And the company's senior debt would be more attractive, since junior debt holders could not trigger a bankruptcy reorganization, which would at least cause the company's bonds to sell temporarily at a discount, and which might leave senior debt holders with inflated reorganization paper.

There are two potential legal obstacles to issuing conversion-option bonds. First, interest payments might be deemed non-deductible because the security resembles equity more than debt. Tax law provides no consistent talisman for debt. Formalities count heavily, even though the cases bristle with warnings that the question is not what the sect1rities "are called, but what in fact they are." denying deductibility to securities of publicly traded corporations which are designated as bonds. Even debt of a closely held corporation will be treated as such, largely on the basis of designation, if the corporation is not highly levered and if the security provides fixed interest payments and a fixed maturity date. ${ }^{11}$

Some cases hold that a fixed maturity date is the major touchstone of debt. ${ }^{12}$ Conventional convertible bonds, however, have a fixed matt1* rity only in the event that the owner chooses not to convert; the "conversion option" bond does not in any greater sense violate a formalistic "fixed maturity" test simply by vesting the choice in the company. Majority clauses and bankruptcy reorganizations already modily the creditor's right to receive the principal at maturity. Although the absolute priority doctrine is supposed to insure that creditors, in a reorganization, will receive new securities equal in value to the face amount of their holdings, the value of the reorganization securities is notoriously overstated. Bankruptcy costs may even place the lender who has this protection in a worse postition than a conversion-option holder. ${ }^{13}$ Moreover, the issuer of a conversion option bond can only

10. Commissioner of Internal Revenue v. J.N. Bray Company, 126 F.2d 612, 619 (5th Cir. 1942).

11. See Comm'r v. O.P.P. Holding Corp., 76 F.2d 11 (2d Cir. 1935); Utility Trailer Mfg. Co. v. United States, 212 F. Supp. 773 (S.D. Calif. 1962); Baker Commoditics Inc. v. Comm'r, 48 T.C. 374 (1967); Garrett Freightlines, Inc., 12 C.C.H. Tax Ct. Mem. 350 (1053); Goldstein, Corporate Indebtedness to Shareholders: "Thin Capitalization" and Relatel Problems, 16 TAx L. REv. 1, 13 (1960). Sometimes deductibility has been upheld even with extreme debt-equity ratios. (The ratio was 400-1 in Leach Corp. v. Comm'r, 90 T.C. 568 (1958), and 700-1 in Baker Commodities v. Comm'r, 48 T.C. 374 (1967)), or extendable maturity dates (H.E. Fletcher Co., 20 P.H. Tax Ct. Memo. I 51317.)

12. Assoc. Investing v. United States, $52 \mathrm{Am}$. Fed. Tax. R. 1210 (D.C. Kan. 1956). Sec John Kelley Co. v. Comm'r, 326 U.S. 521 (1916); McSorley's v. United States, 323 F.2d 900 (10th Cir. 1963); Elko Lamoille Power Co. v. Comm'r, 50 F.2d 595 (9th Cir. 1931).

13. See Brudney, Investment Value Doctrine and Corporate Readjustment, 72 HARY. L. REv. 645, 672 (1959); Frank, Epithetical Jurisprudence and the Work of tha SEC undur 
avoid his obligation to repay the principal amount by converting at a penalty rate. This action may be likened to that of paying liquidated damages. The applicability of the fixed maturity standard to conversion option bonds issued by publicly held corporations may itself be questioned. Most of the cases which have insisted on this standard have involved closely held corporations. Furthermore, many opinions and proposed restatements recognize only the business intent or requirements of the parties as determinative of the issue. ${ }^{14}$

Another frequently used index of non-deductibility is the subordination of the claimed debt to those of trade creditors. ${ }^{15}$ This question also arises mainly in cases which consider close corporations. As applied to a conversion option issued by a publicly held corporation, the subordination issue is identical to that presented by the fixed maturity test. Is the security not debt because the corporation can, at the cost of exercising an onerous option, change its terms of obligation? Once more, the question should turn on the similarity between the exercise of the option and the outcome of reorganization proceedings. If the option ratio is sufficiently steep, the conversion-option bond, viewed at the date of issuance, will offer as firm a non-subordinated status as does a conventional debenture.

The conversion-option bond might be viewed as placing the investor in substance in the same position as a preferred or common stock

Chapter 10 of the Bankruptcy Act, 18 N.Y.U.L.Q. 317, 339-40 (1911); Blum, The Law and Language of Corporate Reorganization, 17 U. CHI. L. REv. 565, $571-80$ (1950).

14. See Welshire \& Western Sandwiches, Inc. v. Conm'r, 175 F.2d 718 (9th Cir. 1919); Utility Trailer MIfg. Co. v. United States, 212 F. Supp. 773 (S.D. Calif. 1962): Baker Commodities, Inc v. Comm'r, 48 T.C. 374 (1967); Hearings on Advisory Group Recom-

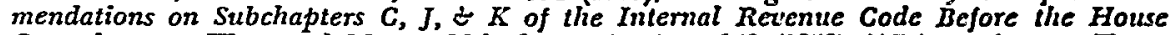
Committee on Ways and Means, 86th Cong., 1st Sess. 859 (1959) (ABA Section on Tasation, Legislative Recommendations In Respect of the Provisions of Subchapter C), Section $\mathrm{C}(4)$ :

(C) DEBT-For all purposes of Subtitle A, indebtedness of a corporation shall be deemed to include (but shall not be limited to) any unconditional obligation of a corporation to pay on demand or on a specified date a sum certain in moncy incurred for an adequate consideration in money or money's worth:

(1) When the obligation is not subordinated by its terns to the claims of trade creditors generally; and

(2) When, by the terms of the obligations, ultimate payment, if any, for use of the principal amount is not dependent upon the carnings of the corporation, and is unconditionally due not later than the maturity date of the principal amount; and

(3) When the principal amount of obligations held in the aggregate by stockholders does not exceed by more than ten to one the fair value of the stock held in the aggregate by stockholders immediately after the obligations are issued; or

(4) In the event that an obligation fails to meet one or more of the other requirements of this subsection, the taxpayer claiming it to be indebtedness established by a preponderance of the evidence that such failure was due to the business requirements of the corporation.

15. See United States v. Snyder Bros. Co., 367 F.2d 950 (5th Gir. 1960); cf. P...r. Finance Corp. v. Comm'r, 302 F.2d 786 (3 Cir. 1962), and cases cited in Note, 56 Micr. L. REv. 1394 (1958). 
holder in regard to his exposure to risk. As argued earlier, however, no debt is free from risk, and contemporary financing methods, e.g., large scale borrowing and low-yield convertibles, offer many examples of equally broad exposure. Even if the company's fortunes plummeted and management exercised the conversion option, the holders of this debt security would, depending on the conversion rate, be three, four, or more times as well off as those who invested in equally priced common stock at the issue date. Moreover, under normal circumstances, management would regard conversion option bondholders as parties adverse to the common shareholders whose interest it is charged to protect. Management would violate its fiduciary duty in exercising the conversion option if the low fortunes of the common did not make it advisable from the shareholders' standpoint.

Of course, the interests of preferred stockholders are also opposed to those of common stockholders, yet preferred dividends are not deductible. The security provisions for the preferred, however, are often less onerous than the penalty conversion rate of our suggested bond. In any case, the distinction between preferred stock and bonds has generally been left to depend on designation. The courts have sus. tained favorable tax treatment of income bonds, which require payment of interest only as earned by the corporation. Even non-cumulative income bonds which offer less protection than cumulative preferreds are upheld. ${ }^{16} \mathrm{~A}$ management which issued conversion option bonds might well choose to maintain interest payments even where there were no earnings, in order to prevent massive dilution of the common. Thus conversion option bonds are likely to have greater security of income than the "income bonds" accepted as legitimate by the courts. By either a formal or substantive test, the deductibility of interest on such bonds should be sustained. ${ }^{17}$

16. Compare John Kelley v. Comm'r, 326 U.S. 521 (1916), with the Circuit Court opinion in Talbot Mills v. Comm'r, 146 F.2d 809 (1st Cir. 1944).

17. The tax status of Conversion Option Bonds may be affected by the Tax Reform Act of 1969. Under the Act the Secretary of the Treasury is empowerca to issue regulations, determining whether a corporate security is debt or equity, These regulations may take into account the certainty of the issuer's obligation to pay a fixed amount it a set date, and the subordination and convertibility of the security.

A more confusing change is an amendment to Section 305 of the Internal Revenuc Code altering drastically the treatment and definition of stock dividends. The amendment. provides for taxation of a distribution of stock which gives some bondliolders property (including cash) and gives others a larger proportionate interest in the company's carnings. To keep within its reach all functional equivalents, the amendment treats rights to acquire stock as stock and holders of convertible security as shareholders, and authorizes the Secretary of the Treasury to prescribe regulations that would treat as distributions a broad range of transactions that increase any shareholder's interest in carnings and profits. Given these definitions, a company's exercise of its conversion option wight be 
The danger of fraud could create other legal obstacles to the conversion option bond. The Securities and Exchange Commission, which has the power to prevent the issuance of "inherently fraudulent" securities, might fear simply that the designation of the security as a bond would mislead purchasers. If the conversion option is hidden in the indenture, investors might give away their bankruptcy rights without getting anything in return. This risk can be minimized if the security is given a distinct name-the title "conversion option" bond would alert investors as do the terms "income bond" and "non-cumulative preferred." The security would then be inherently misleading only if the penalty conversion rate were purely nominal (e.g., 1-1.5), in which case the purchasers of conversion option debt would assume most of the risks of ordinary common stockholders.

Finally, new SEC doctrines on the fiduciary obligation of investment advisors and brokers should help to insure that buyers know what they are buying. The SEG might also fear collusion between management and bondholders to exercise the conversion option even if it is against the interest of the common shareholders. To avoid this danger, one might require management to show that there are no earnings to cover interest payments before it can order conversion. But this requirement is easy to evade, since income and expense items can be shifted between calendar years without great difficulty. Any stricter requirement would defeat the purpose of the conversion option, by maintaining the fixed indebtedness even in times of deep corporate trouble. Alternatively, one could require the approval of a majority of common shareholders before the conversion could be exercised. Only in those cases where the majority of shareholders also owned bonds would the danger of

treated as the payment of a stock dividend. The forced conversion would give the holders of Conversion Option Bonds a larger number of shares than they could obtain by exercising their own conversion rights while the company's release from interest obligations might be interpreted as making possible the continued payments of cash dividend on the company's common stock. Whether the amount of the taxable distribution would be caculated is unclear, although it might be related to the difference between the interest payments on the Conversion Option Bonds and the dividends the former bondholders would receive in their common stock.

Although forced conversion could be brought within the words of the statutes, they are not the kind of distribution Congress appears to have been aiming to tax. The target of the Section 305 amendments was arrangements that permit companies to reward one group of shareholders with capital gains and with cash pay-outs, particularly if the choice is left with the shareholding recipients. A company that excrcised its conversion option, on the other hand, would not be handing out differential rewards: it would be benefiting one class of investors (common stock holders) at the expense of another (the conversion option bondholders). A company would not force a conversion unless the release from interest payments and from the option to pay the principal amount was worth more than the increased interest in the company's earnings and profits going to its conversion option bondholders. To treat the victims of the forced conversion as recipients of a taxable stock dividend would be a perversion of the purposes of the Section 305 amendments. 
fraud remain. Finally, derivative suits could be relied upon to police gross abuses of management discretion.

In sum, neither tax law nor securities regulation should impede an offering of conversion option bonds. The new security would offer the corporation all the advantages of conventional debentures, with fewer risks; it should be worth a try. 